\title{
Research on the Development Status and Countermeasures of Enterprise Earnings Management from the Perspective of Big Data
}

\author{
Tong Zeng*1,a, Zhang Hanyue ${ }^{2, b}$ \\ ${ }^{1}$ School of Management, Shenyang Jianzhu University Hunnan, Shenyang, China \\ ${ }^{2}$ School of Management, Shenyang Jianzhu University Hunnan, Shenyang, China
}

\begin{abstract}
Earnings management plays a leading role in the development of enterprises. With the popularity of big data, when enterprises implement earnings management, analyzing the big data model from the computer can improve the development speed of enterprises. It is not only the key of accounting theory and corporate governance research, but also the top priority in practice. With the continuous development of economy and society in recent years, the problems of interrelated financial have frequently appeared, which leads investors to query the earning ability of related companies. Therefore, this paper studies the current situation of enterprise earnings management from the perspective of big data, and further analyzes the existing problems, and puts forward the countermeasures and suggestions for the relevant enterprise earnings management from the perspective of big data, hoping to standardize the enterprise earnings management behavior and maintain the order of the investment market.
\end{abstract}

\section{INTRODUCTION}

With the continuous improvement of China's economic system, earnings management has become one of the important issues that concerned by many scholars, and a growing number of listed companies have adopted a method of using earnings management to achieve financial reporting objectives. However, in the era of rapid economic development, there are many bad financial phenomena in today's economic market, such as a series of interventions on financial statements for some reasons. Relevant research shows that enterprises need to fulfill their social responsibilities, control excessive earnings management, and safeguard the interests of stakeholders. If the enterprise's management personnel use unreasonable accounting methods without authorization, even if the enterprise can make profits, it will also damage interests of enterprise stakeholders and may also bring losses to the enterprise. If we want to effectively restrain the manipulation behavior of earnings management, we must constantly improve the internal management system of enterprises to help enterprises balance the contradiction between those who pursue interests and those who safeguard interests.

\section{PRESENT SITUATION OF ENTERPRISE EARNNINGS MANAGEMENT FROM THE PERSPECTIVE OF BIG DATA}

\subsection{The Meaning of Earnings Management}

In listed companies, earnings management is a series of accounting behaviors that take place by adopting certain accounting methods in pursuit of maximizing the interests of the company. Its essence is to analyze and interfere the financial statements, so that the beneficiaries can get the greatest benefits from them. It can be seen that earnings management has the following elements: first, the main body of earnings management is the management of enterprises, mainly including managers and board of directors. Secondly, it reflects that the accounting information of an enterprise is the financial statements of the company, which is the main research object of earnings management. Thirdly, the accrual basis is used to manage enterprises and choose a reasonable accounting policy, which is the main operation mode of earnings management. Finally, maximizing shareholders' rights and interests is the most important goal of earnings management. 


\subsection{The Methods of Earnings Management}

The methods of earnings management are to make the management of the enterprise take appropriate measures for the profit of the enterprise, and its main purpose is to maximize shareholders' rights.

\subsubsection{Earnings Management by Using Accounting Standards}

In Chinese modern market, due to the diversification of industries, enterprises are involved in various fields, and at the same time, each company has to deal with business in different ways. Therefore, China has established a set of standards applicable to all enterprises. Only when the accounting standards or the economic market change, the enterprise's accounting methods are revised according to the regulations, and the consistent accounting methods should be adopted under normal circumstances.

\subsubsection{Earnings Management with Government Support}

In order to improve the economic development, the government will provide concessional policies to listed companies to solve the financial crisis of some enterprises. The income from government subsidies will be directly included in the current profits of enterprises, which has a significant effect on improving the performance of enterprises. Under the correct circumstances, the government will also provide appropriate tax incentives for enterprises to be listed soon, with the aim of improving the profits of the current period. When the listed enterprises are short of funds due to excessive interest burden, the government will propose to the banks to implement a reduction and exemption system for the interest owed by the enterprises. This can not only solve the financial problems of enterprises, but also improve the current profits of enterprises.

\subsubsection{Earnings Management by Using Related Party Transactions}

In China, there are many listed enterprises separated from state-owned enterprises, which have strong liquidity and high return rate, and have a close relationship with their related parties. Not only that, for enterprises, the annual performance appraisal is also necessary to improve their own interests through transactions with related parties. When the listed company loses money, the related party will raise the price of goods to buy them or provide financial relief, or sell them to the listed company at a very low price in order to achieve the purpose of profit transfer. If the profits of listed companies are too high, they will trade with their related parties, reduce taxes for enterprises, and then transfer the profits to the parent company.

\subsubsection{Earnings Management by Using Consolidated Financial Statements}

Changing the scope of financial statements are methods used by a host of listed companies in earnings management. There are two main operation forms:(1) A subsidiary transfers or sells all the shares of the company within the scope of the consolidated financial statements of its parent company, and then excludes them when calculating the annual financial statements; (2)When a subsidiary is not within the scope of consolidated financial statements, it can adopt the way of appropriately increasing the proportion of equity or acquiring the company, and summarize the financial information of the subsidiary into the financial statements of its parent company.

\subsubsection{Earnings Management by Using Non-recurring Gains and Losses}

The formation of non-recurring gains and losses is usually incorrect and sudden, and enterprises can not accurately predict it in advance, so the non-recurring gains and losses is extremely temporary and uncertain. In our country, in order to make the lost profits do not affect other rights allotment conditions, enterprises usually take advantage of the contingency of abnormal profits and losses in order to achieve their own interests. Abnormal profit and loss is an important part of enterprises' accounting for total profits. Because of its particularity, it has become one of the common means for enterprises to implement earnings management.

\section{EARNINGS MANAGEMENT OF ENTERPRISES OF INFLUENCE FACTORS AND ANALYSIS FROM THE PERSPECTIVE OF BIG DATA}

\subsection{Influence of Accounting Standards on Earnings Management}

With the rapid development of China's economy, the temptation for accountants is getting bigger and bigger, and it is easy to lose accounting professional ethics, thus using the wrong accounting methods to manage the earnings of enterprises. For example, if you don't want to disclose the true enterprise information to the public, you will falsely report the assets of the enterprise and use the fair value measurement unreasonably. At present, in many enterprises in our country, accountants will take advantage of the imperfect accounting standards, so as to carry out unreasonable earnings management.

\subsection{Influence of Related Party Transactions on Earnings Management}

Due to historical reasons, most of the listed companies in China are the parent companies before the transformation, which leads to the situation that the parent companies are "dominant". At the same time, some complicated related 
party transactions frequently occur between listed companies and their related parties, and the profit transfer between parent companies and subsidiaries is not directly related to whether listed companies have received payment for goods. Companies increase their profits in the current period through leasing, guarantee, agency and providing funds, all of which have a certain impact on the earnings management of enterprises.

\subsection{Influence of Internal Governance Structure on Earnings Management}

In state-owned enterprises, the phenomenon of "monopoly" appears, and the minority shareholders are not interested in the management of the enterprise, but only care about their own value, then the shareholders' meeting will be in name only, and the interests of minority shareholders will be infringed by large shareholders everywhere. As a result of this situation, the chairman and management personnel in state-owned enterprises are highly consistent, even combined into one, which will lead to a serious imbalance in enterprise management. In addition, the staff of the Board of Supervisors are mostly from the management of enterprises. If the shareholders' meeting is not taken seriously, it is conceivable that it is difficult for them to use reasonable accounting methods to manage the earnings of enterprises, which will cause indelible consequences for enterprises.

\subsection{Influence of External Supervision System on Earnings Management}

Auditing of CPA lacks certain independence. There is a principal-agent relationship among the principal, the principal and the auditor in the audit of listed enterprises. The auditee refers to the listed enterprise, and the principal refers to the accounting firm. However, Chinese stateowned shares occupy a dominant position, and the audit clients of listed companies are actually the management personnel of their companies. In this way, the management personnel of our company hire accountants with high salaries to audit and supervise the business of our company. So when choosing clients, they will choose firms that are beneficial to our company. Therefore, it is difficult for accountants of accounting firms to express their true ideas when auditing and supervising listed enterprises, thus lacking certain independence. In the absence of independence of external supervision, it provides a convenient door for enterprises to use earnings management fraud.

\section{Suggestions on Perfecting Enterprise Earnings Management from the Perspective of Big Data}

\subsection{Improve Accounting Standards}

In order to operate accounting practice more flexibly, management personnel should strictly abide by accounting standards. With the constant changes of market economy, the relevant departments that formulate accounting standards in China constantly revise accounting policies, and at the same time, they are constantly strengthening the supervision of the implementation of accounting. China can learn from the successful experiences of other countries, formulate more reasonable accounting standards, and avoid listed companies from making use of the loopholes in accounting standards to conduct unreasonable earnings management.

\subsection{Strictly Control Related Party Transactions}

At present, most of the managers of listed companies in China are non-independent directors, and they can't express their true thoughts. Generally speaking, the interests of enterprises are not directly related to the selfinterests of management. Therefore, the managers lack certain enthusiasm in their work, so that enterprises can trade with related party, and there are big problems in transaction supervision, which leads to the phenomenon of maximizing short-term profits of enterprises. Therefore, listed companies should establish specific punishment measures, strengthen the supervision of related party transactions, and make the transaction process and transaction information more transparent. Strictly supervise the transactions between listed companies and related parties to reduce the probability of earnings manipulation.

\subsection{Improve The Internal Governance Structure of Enterprises}

For a listed company, it is very important to have a good internal structure. Enterprises should improve the internal governance structure, set up independent directors, and independent directors should have independent voting rights, which can objectively and fairly evaluate the current situation of enterprises and maintain the interests of the company. The phenomenon that large shareholders control the whole company is widespread, which makes the existence of various monitoring mechanisms ineffective and provides a great space for unreasonable implementation of earnings management. For the disclosure of listed companies, we should increase the formulation of actual controllers, regularly disclose the change of their equity, the change of holding other listed companies' equity, the actual financial situation of the company, etc., and strengthen the supervision of investors on enterprises. If we don't control the internal governance structure, it will affect the authenticity of the enterprise financial information.

\subsection{Strengthen The External Supervision System}

Many listed companies will use earnings management to control profits because of insufficient external supervision. Establishing a robust external supervision system is a necessary condition for enterprises to carry out correct earnings management. Only under a robust supervision system, the possibility of using earnings management to control profits will be greatly reduced, so as to ensure the 
continuous development of enterprises in the economic market. The supervision of auditing of CPA is weak, which is one of the important reasons why enterprises implement unreasonable earnings management at present. Therefore, the regulatory authorities should strictly check the information disclosure of enterprises, and punish investors for making wrong earnings management in violation of the accounting system. Certified public accountants should correct companies whose information is untrue due to improper earnings management, or hold reservations, so as to warn investors to invest cautiously. In addition, we should strengthen the public's attention to enterprises, improve the ability of investors to analyze the financial information of enterprises, and find that enterprises implement unreasonable earnings management in time, so that the expectation of earnings manipulation by the management of companies will not be achieved.

\section{CONCLUSION}

With the continuous innovation of social and economic system, the competition between enterprises is expanding. In order to safeguard their own interests, they will implement unfair earnings management, which is a common phenomenon in modern economic market. Earnings management refers to the management's regulation of the profits of enterprises under the accounting standards and other relevant legal systems, so as to maximize the profits of enterprises. However, earnings management itself also has financial fraud. Although it is not equivalent to financial fraud, in essence, it violates accounting standards and provides untrue financial information to the public. Moreover, improper use of earnings management for a long time will bring adverse consequences to the future development of enterprises. Therefore, in the future development, listed enterprises should master correct and reasonable earnings management to avoid unnecessary economic crisis and promote healthy and stable development of enterprises.

\section{REFERENCES}

1. Ren Chunyan. Earnings Management and Accounting Standards of Listed Companies [D]. Xiamen university, 2004(2).

2. Huang Weihua, Lu Yujian. Causes and Countermeasures of Earnings Management of Listed Companies in China [J]. Economic Outlook around Bohai Sea, 2002(07):15-18

3. .Rodin. Exploring The Nature and Motivation of Earnings Management [J]. Wealth Life, 2019(6).

4. Gao Yanling. Earnings Management of Listed Companies and Exploration [J]. Shopping Mall Modernization, 2018(7).

5. Yin Lv. Disclosure of Earnings Management and Internal Control Defect Identification Standards-An Empirical Study Based on Disclosure of Mandatory Internal Control Evaluation Report [J]. Audit Research, 2016(04).
6. Guo Xiaofen. Analysis and Discussion on Earnings Management of Listed Companies in China [J]. Management Space, 2011.

7. Xiong Ya'nan. Research on Earnings Management Problems and Countermeasures of Listed Companies in China [J]. Financial Overview, 2014.

8. Lv Yicheng. Research on Earnings Management of Listed Companies [J]. Securities Market, 2016(01).

9. Han Xiao. Enterprise Audit and Earnings Management [J]. Western Leather, 2019,41(16).9596.

10. Du Xingyang.. Analysis of Earnings Management of Listed Companies [J]. Times Economy and Trade, 2017(19).

11. Liu Yaman. The Means and Identification Methods of Earnings Management of Listed Companies in China [J]. Northern Economic and Trade, 2006,000(006):83-85. 